\title{
PENERAPAN PEMBELAJARAN DENGAN "CHEMISTRY MYSTERY BOX” PADA MATERI SISTEM KOLOID UNTUK MENINGKATKAN KETERAMPILAN BERPIKIR KREATIF DAN KOLABORASI SISWA
}

\author{
The Application Of Learning with The "Chemistry Mystery Box" to A \\ Coloidal System Material to Improve Student's Creative Thinking and \\ Collaboration Skill
}

\section{Rahimah*, Atiek Winarti, Parham Saadi}

Program Studi Pendidikan Kimia FKIP Universitas Lambung Mangkurat, Jl. Brigjend. H. Hasan Basry Banjarmasin 70123 Kalimantan Selatan Indonesia *email: rahimahrara97@gmail.com

\begin{abstract}
Abstrak. Penelitian ini bertujuan untuk mengetahui peningkatan 1) keterampilan berpikir kreatif, 2) hasil belajar pengetahuan, 3) keterampilan kolaborasi, dan 4) hasil belajar aspek sikap siswa SMA Negeri 6 Banjarmasin melalui penerapan pembelajaran dengan "chemistry mystery box" pada materi sistem koloid. Metode yang dipakai adalah quasi experiment dengan desain "nonequivalent control group". Sampel penelitian, yaitu kelas eksperimen sebanyak 34 orang dan kelas kontrol sebanyak 35 orang. Pengumpulan data menggunakan instrumen tes (keterampilan berpikir kreatif dan hasil belajar pengetahuan) dan instrumen non tes berupa angket respon siswa dan observasi (keterampilan kolaborasi dan hasil belajar aspek sikap) melalui analisis deskriptif dan uji-t. Adapun variabel bebas dalam penelitian adalah model pembelajaran dan variabel terikatnya adalah keterampilan (berpikir kreatif dan kolaborasi), hasil belajar (pengetahuan dan sikap). Hasil yang diperoleh menunjukkan 1) tingkat pencapaian keterampilan berpikir kreatif siswa kelas eksperimen sebesar 77,39\% dan kelas kontrol sebesar 73,46\% 2) N-gain hasil belajar pengetahuan siswa kelas eksperimen sebesar 0,73 berkualifikasi tinggi dan kelas kontrol sebesar 0,63 berkualifikasi sedang 3) rata-rata keterampilan kolaborasi siswa kelas eksperimen sebesar 76,85\% dan kelas kontrol sebesar $70,29 \%$ 4) rata-rata hasil belajar aspek sikap siswa kelas eksperimen sebesar 3,96 dan kelas kontrol sebesar 3,5.
\end{abstract}

Kata kunci: Project Based Learning, chemistry mystery box, keterampilan berpikir kreatif, keterampilan kolaborasi, dan sistem koloid.

\begin{abstract}
This research aims to determine improvement 1) creative thinking skills, 2) knowledge learning outcomes, 3) collaboration skills, and 4) learning outcomes aspects of the attitude of students of SMA Negeri 6 Banjarmasin through the application of learning with "chemistry mystery box" on the colloidal system material. The method used is a quasi experiment with the design of "nonequivalent control group". The sample of the research is 34 experimental classes and 35 control classes. Data collection using test instruments (creative thinking skills and cognitive outcomes of students) and nontest instruments in the form of questionnaires for student responses and observations (collaboration skills and attitudes learning outcomes) through descriptive analysis and t-test. The independent variable in the research is the learning model and the dependent variable is skills (creative thinking and collaboration), learning outcomes (knowledge and attitudes). The results obtained show the level of achievement of students' creative thinking skills in the experimental class was $77.39 \%$ and the control class was $73.46 \%$ 2) The $\mathrm{N}$ gain of students' learning outcomes in the experimental class was 0.73 highly qualified and the control class 0.63 was moderately qualified 3) the average
\end{abstract}

Copyright $\odot$ JCAE-Jurnal Tugas Akhir Mahasiswa, e-ISSN 2613-9782

Program Studi Pendidikan Kimia FKIP Universitas Lambung Mangkurat 
collaboration skills of the experimental class students was $76.85 \%$ and the control class was $70.29 \%$ 4) the average learning outcomes of the attitude aspects of the experimental class students amounted to 3.96 and the control class 3.5.

Keywords: Project Based Learning, chemistry mystery box, creative thinking skill, collaboration skills, and a coloidal system.

\section{PENDAHULUAN}

Menurut Grenstein (2012), siswa yang hidup di abad 21 dalam proses pembelajaran harus mampu mengembangkan keterampilan 4C (berpikir kritis, kreatif, kolaborasi, dan komunikasi) secara efektif agar produktif, sehingga siswa harus memiliki keterampilan 4C yang baik. Namun, pada kenyataannya dalam pembelajaran masih ada siswa yang kurang kreatif dan kolaboratif.

Rendahnya kreativitas siswa dikarenakan pembelajaran disekolah yang dilatihkan adalah hafalan dan kemampuan berpikir konvergen. Akibatnya siswa kesulitan dalam menyelesaikan masalah dan mencari solusi dari permasalahan tersebut (Fatmawati, 2011). Guru mata pelajaran kimia SMAN 6 Banjarmasin menyatakan kurangnya pemahaman siswa terhadap materi pelajaran yang diberikan membuat siswa kesulitan dalam mengemukakan gagasan atau ide karena siswa terbiasa berpikir konvergen yang mengakibatkan kurangnya kreativitas siswa. Selain itu, keterampilan kolaborasi siswa juga masih rendah dan kurangnya tanggung jawab terhadap tugas yang diberikan sehingga tujuan bersama akan sulit dicapai. Buktinya, ketika guru memberikan tugas kelompok, siswa bekerja sendiri-sendiri, bahkan saat proses diskusi kelompok sebagian siswa berbicara ataupun bermain. Inilah faktor penyebab hasil belajar rendah.

Karakteristik materi sistem koloid dalam kurikulum 2013 yang menjadi sasaran dalam dimensi pengetahuan menuntut adanya kreativitas dan kolaboratif siswa. Karakteristik tersebut harus diajarkan menggunakan model pembelajaran yang cocok, yaitu pembelajaran yang mengajarkan tentang konseptual disertai contohcontoh yang bersifat faktual dan harus melakukan sendiri proyek yang bersifat prosedural. Siswa untuk dapat berpikir kreatif harus mencoba sendiri proyek yang dilakukan dan keterampilan kolaborasi siswa harus bekerja sama, bertanggungjawab terhadap tugasnya, sehingga untuk mencapai sasaran diperlukan model pembelajaran Project Based Learning.

Model pembelajaran Project Based Learning merupakan pembelajaran yang menggunakan proyek sebagai tujuan akhirnya. Jenis masalah yang dipakai adalah masalah yang bersifat faktual. Chemistry mystery box merupakan sebuah proyek yang dibuat siswa dengan pembelajaran Project Based Learning. Chemistry mystery box berupa sebuah media pembelajaran yang dapat membantu siswa dalam memahami pelajaran yang diberikan. Materi yang cocok menggunakan proyek ini adalah materi sistem koloid terlihat dari kompetensi dasar sistem koloid.

Proyek ini berbentuk sebuah box yang didalamnya berisi permasalahan berdasarkan masalah nyata yang ada dalam kehidupan. Permasalahan ini diberikan guru kepada kelompok kolaboratif sesuai materi yang dipelajari. Permasalahan yang diberikan berbeda-beda antarkelompok kolaboratif sehingga ide-ide, gagasan, ataupun solusi yang diberikan oleh kelompok kolaboratif juga berbeda-beda sesuai dengan permasalahan yang didapatnya kemudian dikemas sekreatif mungkin. Tugas pembuatan proyek ini bertujuan untuk mengukur seberapa besar kreativitas siswa dilihat dari banyaknya ide atau gagasan yang dikemukakan dalam memecahkan masalah dan keterampilan kolaborasi siswa dilihat dari bagaimana interaksi sosialnya 
dengan teman maupun dengan guru.

Hal ini sejalan dengan Anwar, Aness, Khizar, Naseer, \& Muhammad (2012) dan Smaraba, Arnyana, \& Setiawan (2013), keterampilan berpikiri kreatif siswa dapat dilihat dari bagaimana siswa menghasilkan gagasan baru dan menciptakan sesuatu yang baru, sehingga penting ditanamkan karena dengan berkreasi orang dapat mewujudkan dirinya.

Berdasarkan hasil penelitian Sari, Prasetyo, \& Wibowo (2017) dan Yuliana, Prasetyo \& Hastuti (2018) menunjukkan terjadi peningkatan kolaborasi siswa yang menggunakan LKPD IPA dan kreativitas siswa yang menggunakan modul IPA berbasis Project Based Learning berkategori sedang dari kategori "cukup" menjadi "baik".

Model pembelajaran Project Based Learning dapat diterapkan disekolah ataupun diperguruan tinggi karena model pembelajaran ini memiliki peranan penting dalam menciptakan pengalaman bermakna bagi siswa sebelum memasuki dunia kerja yang sesungguhnya. Dimana dalam dunia kerja seseorang harus memiliki kemampuan interpersonal dan manajemen proyek yang menuntut adanya kerja tim. Pengalaman bermakna yang di maksud adalah untuk dapat melatihkan keterampilan kolaborasi yang baik antar siswa (Saenab, Yunus, \& Virninda, 2017).

William (dalam Kusmana, 2014), menyatakan bahwa indikator berpikir kreatif siswa meliputi: kelancaran (fluency), keluwesan (flexibility), keaslian (originality), keterincian (elaboration), dan evaluasi (evaluation). Indikator keterampilan kolaborasi menurut Sari, Prasetyo, \& Wibowo (2017) meliputi: berkontribusi secara aktif, bekerja secara produktif, menunjukkan fleksibilitas dan berkompromi, mengelola proyek dengan baik, menunjukkan tanggungjawab dan sikap respek.

Berdasarkan pemaparan di latar belakang penelitian ini bertujuan untuk mengetahui peningkatan kreativitas dan kolaboratif siswa menggunakan proyek chemistry mystery box pada materi sistem koloid.

\section{METODE PENELITIAN}

Metode yang dipakai dalam penelitian adalah quasi experiment dengan desain "nonequivalent control group". Sampel penelitian, yaitu kelas eksperimen sebanyak 34 orang dan kelas kontrol sebanyak 35 orang. Kegiatan pengajaran dilakukan sebanyak empat pertemuan pada setiap kelas. Penelitian ini memakai teknik pengumpulan data tes keterampilan berpikir kreatif dan hasil belajar pengetahuan yang dilakukan pada pertemuan awal dan pertemuan akhir dan teknik nontes berupa observasi keterampilan kolaborasi dan hasil belajar aspek sikap serta angket respon melalui analisis deskriptif dan uji-t.

Hasil keterampilan berpikir kreatif dan hasil belajar pengetahuan siswa dianalisis menggunakan uji-t. Instrumen tes berupa 3 soal uraian untuk keterampilan berpikir kreatif dan 15 soal pilihan ganda untuk hasil belajar pengetahuan. Hasil keterampilan kolaborasi, hasil belajar pada aspek sikap, dan respon siswa dianalisis menggunakan analisis deskriptif. Adapun pengkategorian keterampilan berpikir kreatif menurut Herlina \& Qurbaniah (2017) dengan kategori sangat tinggi, tinggi, cukup tinggi, rendah dan sangat rendah dan kolaborati siswa menurut Widoyoko (2015) dengan kategori sangat baik, baik, cukup, kurang, dan sangat kurang.

\section{HASIL PENELITIAN DAN PEMBAHASAN \\ A. Analisis keterampilan berpikir kreatif}

Analisis ini membandingkan kelas eksperimen dan kelas kontrol setelah diberi perlakuan. Keterampilan berpikir kreatif (tes akhir) kelas eksperimen dibanding kelas kontrol lebih unggul. Setelah dihitung menggunakan uji-t kedua kelas berbeda secara 
siginifikan.

Perbedaan dikarenakan adanya pengaruh dari pembelajaran dengan menggunakan proyek chemistry mystery box pada kelas eksperimen yang mengharuskan siswa mengkaji sendiri konsep materi sistem koloid dan menghubungkan konsep tersebut dengan permasalahan nyata dalam kehidupan (sasirangan, kabut asap, fogging nyamuk, pemutihan gula dan penggumpalan cat), serta menyelesaikan sendiri proyek yang diberikan yang membuat siswa fluency (berpikir lancar), flexibility (berpikir luwes), originality (berpikir asli), dan elaboration (berpikir rinci) yang tidak ada pada model pembelajaran Direct Instruction. Hal ini terdapat pada Tabel 1 uji-t dan Tabel 2 nilai $N$-Gain kedua kelas.

Tabel 1. Perbandingan uji-t data pre-creative dan post-creative

\begin{tabular}{|c|c|c|c|c|c|c|c|}
\hline Hasil & Kelas & Db & $\overline{\mathbf{x}}$ & $\mathrm{SD}^{2}$ & $t_{\text {hitung }}$ & $\begin{array}{c}\text { ttabel } \\
\mathbf{5 \%}\end{array}$ & Kesimpulan \\
\hline \multirow{2}{*}{ Pre-creative } & Eksperimen & \multirow{2}{*}{67} & 29,48 & 66,53 & \multirow{2}{*}{0,46} & \multirow{2}{*}{2,00} & \multirow{2}{*}{$\begin{array}{c}\text { Tidak berbeda } \\
\text { secara } \\
\text { signifikan }\end{array}$} \\
\hline & Kontrol & & 28,63 & 49,61 & & & \\
\hline \multirow{2}{*}{ Post-creative } & Eksperimen & \multirow{2}{*}{67} & 77,39 & 26,78 & \multirow{2}{*}{3,26} & \multirow{2}{*}{2,00} & \multirow{2}{*}{$\begin{array}{c}\text { Berbeda } \\
\text { secara } \\
\text { signifikan }\end{array}$} \\
\hline & Kontrol & & 73,46 & 23,22 & & & \\
\hline
\end{tabular}

Tabel 2. Interpretasi $N$-gain

\begin{tabular}{lcccc}
\hline \multirow{2}{*}{ Indikator } & \multicolumn{2}{c}{ Kelas Eksperimen } & & Kelas Kontrol \\
\cline { 2 - 5 } & $\langle\boldsymbol{g}\rangle$ & Tingkat Pencapaian & $\langle\boldsymbol{g}\rangle$ & Tingkat Pencapaian \\
\hline Fluency/Originality & 0,96 & Tinggi & 0,93 & Tinggi \\
Flexibility & 0,49 & Sedang & 0,46 & Sedang \\
Elaboration & 0,62 & Sedang & 0,53 & Sedang \\
Rata-Rata & 0,68 & Sedang & 0,63 & Sedang \\
\hline
\end{tabular}

Tabel 2 memperlihatkan seberapa besar perbedaan $N$-gain yang diperoleh kedua kelas untuk mengetahui peningkatan keterampilan berpikir kreatif. $\mathrm{N}$-gain kedua kelas berada pada kualifikasi tinggi dan sedang. Rata-rata $\mathrm{N}$-gain kelas eksperimen dibanding kelas kontrol lebih unggul walaupun perbedaannya relatif kecil. Hal ini disebabkan waktu pembelajaran yang relatif singkat sehingga pembelajaran Project Based Learning dengan proyek chemistry mystery box menjadi kurang optimal. Namun, masih dapat dikatakan peningkatan keterampilan berpikir kreatif kelas eksperimen dibanding kelas kontrol lebih baik pada materi sistem koloid, sehingga dapat disimpulkan penerapan pembelajaran menggunakan proyek chemistry mystery box memperlihatkan dampak positif terhadap kreativitas siswa.

Tabel 3. Persentase tingkat pencapaian keterampilan berpikir kreatif

\begin{tabular}{lcccc}
\hline \multirow{2}{*}{ Nilai } & \multicolumn{2}{c}{ Kelas eksperimen } & \multicolumn{2}{c}{ Kelas kontrol } \\
\cline { 2 - 5 } & Pre-creative & Post-creative & Pre-creative & Post-creative \\
\hline Fluency/Originality & 37,45 & 97,84 & 35,81 & 95,24 \\
Flexibility & 27,06 & 63,14 & 28,57 & 61,71 \\
Elaboration & 23,92 & 71,18 & 21,52 & 63,43 \\
Rata-Rata & 29,48 & 77,39 & 28,63 & 73,46 \\
\hline
\end{tabular}

Pada Tabel 3, indikator fluency dan originality memiliki persentase tertinggi, sedangkan indikator flexibility memiliki persentase terendah. Indikator fluency dan originality memiliki persentase tertinggi disebabkan siswa mampu menyelesaikan masalah atau pertanyaan terhadap permasalahan yang dihadapi yang melahirkan pemikiran kreatif dengan mencetuskan banyak ide atau gagasan serta jawaban, dan 
melahirkan ungkapan yang baru dan unik, sedangkan indikator flexibility memiliki persentase terendah disebabkan siswa masih belum tepat menuliskan jawaban atau masih terdapat kekeliruan dalam menjelaskan jawaban dari permasalahan yang dihadapi. Kelas eksperimen memiliki persentase tingkat pencapaian keterampilan berpikir kreatif lebih unggul dibandingkan kelas kontrol.

Temuan penelitian didukung dengan hasil penelitian Nurdin, Sulastry \& Hasri (2018), Yuliana, Prasetyo \& Hastuti (2018), Ulfah, Bakti \& Saadi (2018), dan Nehe (2017) serta Wahyu, Rusmansyah \& Sholahuddin (2017), yang menunjukkan penerapan pembelajaran berbasis proyek berupa media pembelajaran lebih baik karena siswa berperan aktif dalam pembelajaran yang dapat meningkatkan kreativitas dibandingkan tanpa menggunakan media pembelajaran dan keterampilan berpikir tingkat matematis termasuk keaslian, elaborasi, kelenturan dan kefasihan. Indikator flexibility terlihat dari kemampuan siswa dalam memecahkan masalah.

\section{B. Analisis Hasil Belajar Pengetahuan}

Tabel 4 memperlihatkan kedua kelas berbeda signifikan setelah diberi posttest pada akhir penelitian. Tabel 5 menunjukkan seberapa besar perbedaan $N$-gain yang diperoleh kedua kelas untuk mengetahui peningkatan hasil belajar pengetahuan. Hasil $\mathrm{N}$-gain kelas eksperimen berkualifikasi tinggi dan kelas kontrol berkualifikasi sedang, sehingga peningkatan pengetahuan kelas eksperimen dibanding kelas kontrol lebih unggul pada materi sistem koloid.

Pengetahuan siswa kelas eksperimen meningkat karena adanya perbedaan perlakuan yang diberikan oleh guru. Penggunaan proyek chemistry mystery box dalam pembelajaran lebih efektif dalam meningkatkan hasil belajar pengetahuan karena penerapan chemistry mystery box membuat siswa lebih memahami dan mampu mengaitkan konsep-konsep materi sistem koloid dalam kehidupan dengan cara yang menyenangkan.

Tabel 4. Uji-t data hasil pretest dan posttest hasil belajar pengetahuan

\begin{tabular}{|c|c|c|c|c|c|c|c|}
\hline Hasil & Kelas & Db & $\overline{\mathrm{X}}$ & $\mathrm{SD}^{2}$ & thitung & $\begin{array}{c}\mathbf{t}_{\text {tabel }} \\
5 \%\end{array}$ & Kesimpulan \\
\hline \multirow{2}{*}{$\begin{array}{l}\text { Tes awal } \\
\text { (Pretest) }\end{array}$} & Eksperimen & \multirow{2}{*}{67} & 30,00 & 73,40 & \multirow{2}{*}{1,82} & \multirow{2}{*}{2,00} & \multirow{2}{*}{$\begin{array}{c}\text { Tidak berbeda } \\
\text { secara signifikan }\end{array}$} \\
\hline & Kontrol & & 25,90 & 101,36 & & & \\
\hline \multirow{2}{*}{$\begin{array}{l}\text { Tes akhir } \\
\text { (Posttest) }\end{array}$} & Eksperimen & \multirow{2}{*}{67} & 80,59 & 87,19 & \multirow{2}{*}{3,70} & \multirow{2}{*}{2,00} & \multirow{2}{*}{$\begin{array}{l}\text { Berbeda secara } \\
\text { signifikan }\end{array}$} \\
\hline & Kontrol & & 72,00 & 98,82 & & & \\
\hline
\end{tabular}

Tabel 5. Interpretasi $N$-gain

\begin{tabular}{ccc}
\hline Kelas & $\langle\mathbf{g}\rangle$ & Kualifikasi \\
\hline Eksperimen & 0,73 & Tinggi \\
Kontrol & 0,63 & Sedang \\
\hline
\end{tabular}

Temuan penelitian didukung dengan hasil penelitian Fitria (2017) dan Purnamasari, Leny \& Saadi (2014), yang menyatakan model pembelajaran Project Based Learning dapat meningkatkan hasil belajar dimana siswa dapat membangun, melakukan dan memperbaiki pengetahuannya sehingga konsep yang mereka temukan melekat dalam ingatannya.

\section{Analisis Keterampilan Kolaborasi}

Tabel 6 memperlihatkan kelas eksperimen memperoleh hasil keterampilan kolaborasi siswa lebih unggul dibanding kelas kontrol. Keterampilan kolaborasi siswa kelas eksperimen meningkat setiap pertemuannya dibanding kelas kontrol 
dikarenakan pada kelas eksperimen siswa mengerjakan sendiri proyek yang mengharuskan adanya kerja tim yang baik, sehingga adanya proyek chemistry mystery box ini dapat mengasah dan melatihkan keterampilan kolaborasi siswa.

Hasil temuan ini sejalan dengan penelitian Mahanal, Ericka, Corebima \& Zubaidah (2017) dan Anantyarta \& Sari (2017), yang menyatakan bahwa adanya perbedaan signifikan antara siswa yang menerapkan model pembelajaran Project Based Learning dengan model konvensional (Direct Instruction) dan keterampilan kolaboratif siswa berada pada tingkat yang baik.

Tabel 6. Rata-rata skor perbandingan hasil keterampilan kolaborasi siswa

\begin{tabular}{|c|c|c|}
\hline Indikator yang diamati & Eksperimen & Kontrol \\
\hline Berkontribusi secara aktif & 73,82 & 65,91 \\
\hline Kategori & Baik & Baik \\
\hline Bekerja secara produktif* & 75,10 & - \\
\hline Kategori & Baik & - \\
\hline Menunjukkan fleksibilitas dan berkompromi & 74,90 & 68,95 \\
\hline Kategori & Baik & Baik \\
\hline Mengelola proyek dengan baik* & 77,45 & - \\
\hline Kategori & Baik & - \\
\hline Menunjukkan tanggung jawab & 75,29 & 70,10 \\
\hline Kategori & Baik & Baik \\
\hline Menunjukkan sikap respek & 84,51 & 76,19 \\
\hline Kategori & Sangat baik & Baik \\
\hline Rata-Rata & 76,85 & 70,29 \\
\hline Kategori & Baik & Baik \\
\hline
\end{tabular}

\section{Analisis Hasil Belajar Aspek Sikap}

Tabel 7 menunjukkan hasil belajar sikap kelas eksperimen dibanding kelas kontrol lebih tinggi pada semua aspek yang diamati, sehingga hasil ini menunjukkan bahwa secara keseluruhan penerapan pembelajaran dengan proyek chemistry mystery box memperlihatkan dampak positif terhadap aspek sikap.

Tabel 7. Rata-rata skor perbandingan hasil belajar aspek sikap siswa

\begin{tabular}{ccc}
\hline Sikap diamati & Eksperimen & Kontrol \\
\hline Rasa ingin tahu & 3,59 & 3,23 \\
Kategori & Baik & Baik \\
Tanggung jawab & 3,91 & 3,57 \\
Kategori & Baik & Baik \\
Kerjasama & 4,38 & 3,70 \\
Kategori & Sangat baik & Baik \\
\hline
\end{tabular}

Temuan ini sejalan dengan penelitian Sadiqin, Istyadji, \& Winarti (2017) dan Pradita, Mulyani \& Redjeki (2015), yang menyatakan mengoptimalkan potensi otak kanan terkait proses non verbal, yaitu kreativitas dapat memicu motivasi, rasa ingin tahu dan kerja sama siswa serta pembelajaran Project Based Learning mendorong keaktifan, mempunyai toleransi yang tinggi dan mampu memberi pertanyaan dan solusi dari pertanyaan yang diberikan oleh teman ataupun guru.

\section{E. Analisis Respon Siswa}

Tabel 8 menunjukkan hasil respon yang sangat baik terhadap pembelajaran yang menggunakan proyek chemistry mystery box. 
Tabel 8. Skor respon kelas eksperimen

\begin{tabular}{|c|c|c|c|c|c|c|c|c|c|c|c|}
\hline & \multicolumn{10}{|c|}{ Pernyataan } & \multirow{2}{*}{ Jumlah } \\
\hline & 1 & 2 & 3 & 4 & 5 & 6 & 7 & 8 & 9 & 10 & \\
\hline Rata-rata & 4,24 & 4,15 & 4,24 & 4,24 & 4,03 & 4,38 & 4,35 & 4,18 & 4,15 & 4,21 & 42,17 \\
\hline Kategori & SS & SS & SS & SS & SS & SS & SS & SS & SS & SS & $\begin{array}{c}\text { Sangat } \\
\text { baik }\end{array}$ \\
\hline
\end{tabular}

Hasil temuan ini sejalan dengan penelitian Mardiana (2017), dimana respon siswa yang belajar dengan model pembelajaran Project Based Learning membuat siswa lebih menyukai pelajaran dibandingkan model pembelajaran konvensional (Direct Instruction).

\section{SIMPULAN}

1) keterampilan berpikir kreatif siswa berbeda signifikan antara kelas eksperimen dengan persentase 77,39\% dan kelas kontrol 73,46\%; 2) hasil belajar pengetahuan siswa berbeda signifikan antara kelas eksperimen dengan $\mathrm{N}$-gain 0,73 berkualifikasi tinggi dan kelas kontrol 0,63 berkualifikasi sedang; 3) keterampilan kolaborasi kelas eksperimen lebih unggul dengan persentase $76,85 \%$ dibanding kelas kontrol 70,29\%; 4) Sikap kelas eksperimen dibanding kelas kontrol lebih baik; dan 5) respon sangat baik terhadap pembelajaran dengan proyek chemistry mystery box. Penerapan pembelajaran dengan chemistry mystery box memberikan dampak sangat positif terhadap kreativitas dan kolaborasi siswa.

\section{DAFTAR RUJUKAN}

Anwar, M. N., Aness, M., Khizar, A., Naseer, M., \& Muhammad, G. (2012). Relationship of Creative Thinking with the Academic Achievements of Secondary School Students. International Interdisciplinary Journal of Education, 1(3), 44-47.

Anantyarta, P. A \& Sari, R. L. I. (2017). Keterampilan Kolaboratif Dan Metakognitif Melalui Multimedia Berbasis Means Ends Analysis. Jurnal Biologi dan Pembelajaran Biologi, 2(2), 33-43.

Fatmawati, B. (2011). Pembelajaran Berbasis Proyek untuk Meningkatkan Keterampilan Berpikir Kreatif Mahasiswa. Jurnal Pengajaran MIPA, 16(2), 85-95.

Fitria, A. (2017). Pengaruh Model Pembelajaran Project Based Learning Terhadap Hasil Belajar Siswa Pada Materi Koloid di MAN Indrapuri Aceh Besar. Jurnal Universitas Islam Negeri Ar-raniry.1(2).

Greenstein, L. (2012). Assessing 21st Century Skill: A Guide to Evaluating Mastery and Authentic Learning. United States of America: Corwin A Sage Company.

Herlina, L., \& Qurbaniah, M. (2017). Analisis Kemampuan Berpikir Kreatif Siswa Pada Materi Virus Kelas X Mas Al-Mustaqim Sungai Raya 2. Jurnal Bioeducation, 2(1), 11-14.

Kusmana. (2014). Kemampuan Berpikir Kreatif Matematis. Makalah pada Pengantar Kurikulum. FITK UIN Syarif Hidayatullah, Jakarta. Tidak dipublikasikan.

Mahanal, S., Ericka Darmawan, A. D., Corebima., \& Zubaidah, S. (2017). Pengaruh Pembelajaran Project Based Learning (PjBL) Pada Materi Ekosistem Terhadap Sikap dan Hasil Belajar Siswa SMAN 2 Malang. Jurnal Biologi FMIPA Universitas Negeri Malang, 1(1).

Mardiana, R. (2017). Pengaruh Model Pembelajaran Berbasis Proyek (PjBL) Terhadap Hasil Belajar Siswa Pada Konsep Impuls dan Momentum. Skripsi Program Studi Pendidikan Fisika. Universitas Islam Negeri Syarif Hidayatullah. 
Nehe, M., Edy Surya., \& Syahputra, E. (2017). Creative Thinking Ability to Solving Equation an Non-Equation of Linear Single Variable in VII Grade Junior High School. Journal of advance research and Innovative Ideas in Education, 3.

Nurdin, F. S., Sulastry, T., \& Hasri. (2018). Pengaruh Penggunaan Media Pembelajaran Berbasis Macromedia Flash 8 Pada Model Pembelajaran Kooperatif Melalui Pendekatan Saintifik Terhadap Motivasi dan Hasil Belajar (Study Pada Materi Pokok Laju Reaksi). Chemistry education review (CER), 1, 29-43.

Pradita, Y., Mulyani, B., \& Redjeki, T. (2015). Penerapan Model Pembelajaran Project Based Learning untuk Meningkatkan Prestasi Belajar dan Kreativitas Siswa Pada Materi Pokok Sistem Koloid Kelas XI IPA Semester Genap Madrasah Aliyah Negeri Klaten Tahun Pelajaran 2013/2014. Jurnal Pendidikan Kimia, 4(1), 89-96.

Saenab, S., Yunus, S.R., \& Virninda, A.N. (2017). PjBL untuk Pengembangan Keterampilan Mahasiswa: Sebuah Kajian Deskriptif tentang Peran PjBL dalam Melejitkan Keterampilan Komunikasi dan Kolaborasi Mahasiswa. Artikel: Universitas Negeri Makassar. http://ojs.unm.ac.id/semnaslemlit/article/viewFile/3739/2136.

Sadiqin, I. K., Istiadji, M., \& Winarti, A. (2017). Mengoptimalkan Potensi Otak Kanan Siswa dalam Pembelajaran Kimia. Quantum, Jurnal Inovasi Pendidikan Sains, 7 (1), 27-35.

Sari, K.A., Prasetyo, Z.K., \& Wibowo, W.S. (2017). Pengembangan Lembar Kerja Peserta Didik Berbasis Model Project Based Learning untuk Meningkatkan Keterampilan Kolaborasi dan Komunikasi Peserta Didik Kelas VII. Jurnal Pendidikan Ilmu Pengetahuan Alam-S1, 6(8).

Smarabawa, I., Arnyana, I., \& Setiawan, I. (2013). Pengaruh Model Pembelajaran Sains Teknologi Masyarakat terhadap Pemahaman Konsep Biologi dan Keterampilan Berpikir Kreatif Siswa SMA. e-Journal Pendidikan Pascasarjana Universitas Pendidikan Ganesha, 3, 1-28.

Ulfah, M., Bakti, I., \& Saadi, P. (2018). Penerapan Pembelajaran Project Based Learning dengan Tungas Mind-Map Pada Materu Larutan Penyangga. Jurnal Pendidikan Kimia, 1(2), 1-8.

Wahyu., Rusmansyah., \& Sholahuddin. A. (2017). Meningkatkan Kemampuan Berpikir Kreatif dan Self Efficacy Siswa Menggunakan Model Creative Problem Solving Pada Materi Sistem Koloid. Jurnal Pendidikan Kimia, 1(1).

Widoyoko, E. P. (2017). Penilaian Hasil Pembelajaran di Sekolah. Yogyakarta: Pustaka Belajar.

Yuliana., Prasetyo, Z.K., \& Hastuti, P.W. (2018) Pengembangan Modul IPA Berbasis Project Based Learning untuk Menumbuhkan Kreativitas Peserta Didik Kelas VII SMP. Jurnal Pendidikan Ilmu Pengetahuan Alam-S1, 7(4). 